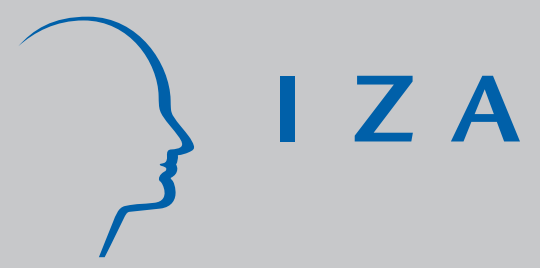

IZA DP No. 52

Fertility Assimilation of Immigrants:

Evidence from Count Data Models

J ochen Mayer

Regina T. Riphahn

August 1999 


\title{
Fertility Assimilation of Immigrants: Evidence from Count Data Models
}

\author{
Jochen Mayer \\ University of Munich, Germany and IZA, Bonn, Germany \\ Regina T. Riphahn \\ University of Munich, Germany, IZA, Bonn, Germany and CEPR, London
}

Discussion Paper No. 52
August 1999

\author{
IZA \\ P.O. Box 7240 \\ D-53072 Bonn \\ Germany \\ Tel.: +49-228-3894-0 \\ Fax: +49-228-3894-210 \\ Email: iza@iza.org
}

This Discussion Paper is issued within the framework of IZA's research area The Welfare State and Labor Markets. Any opinions expressed here are those of the author(s) and not those of the institute. Research disseminated by IZA may include views on policy, but the institute itself takes no institutional policy positions.

The Institute for the Study of Labor (IZA) in Bonn is a local and virtual international research center and a place of communication between science, politics and business. IZA is an independent, nonprofit limited liability company (Gesellschaft mit beschränkter Haftung) supported by the Deutsche Post AG. The center is associated with the University of Bonn and offers a stimulating research environment through its research networks, research support, and visitors and doctoral programs. IZA engages in (i) original and internationally competitive research in all fields of labor economics, (ii) development of policy concepts, and (iii) dissemination of research results and concepts to the interested public. The current research program deals with (1) mobility and flexibility of labor markets, (2) internationalization of labor markets and European integration, (3) the welfare state and labor markets, (4) labor markets in transition, (5) the future of work, and (6) general labor economics.

IZA Discussion Papers often represent preliminary work and are circulated to encourage discussion. Citation of such a paper should account for its provisional character. 
IZA Discussion Paper No. 52

August 1999

\section{ABSTRACT}

\section{Fertility Assimilation of Immigrants: Evidence from Count Data Models}

This study applies count data estimation techniques to investigate the fertility adjustment of immigrants in the destination country. Data on completed fertility are taken from the 1996 wave of the German Socioeconomic Panel (GSOEP). While the economic literature stresses the role of prices and incomes as determinants of fertility, the demographic literature discusses whether assimilation or disruption effects dominate immigrants' fertility after migration. We find evidence in favor of the assimilation model according to which immigrant fertility converges to native levels over time. In addition, we confirm the negative impact of female human capital on fertility outcomes.

JEL Classification: C25, J13, J61

Keywords: Count data estimation, immigrant fertility, assimilation, disruption

Regina T. Riphahn

University of Munich

Ludwigstr. 28 RG

80539 Munich

Germany

Email: Regina.Riphahn@selapo.vwl.uni-muenchen.de

\footnotetext{
"We wish to thank Julia Dannenberg for very able research assistance and the editor and three anonymous referees, Ralph Rotte, and seminar participants at IZA-Bonn and the University of Munich for helpful comments.
} 


\section{Introduction}

Immigrants' assimilation to destination country standards is discussed in a wide and growing literature. Past assimilation research has focused on labor market aspects such as earnings, unemployment, ${ }^{1}$ or transfer program participation. ${ }^{2}$ With continuously accelerating flows of international migration (cf. Segal 1993) issues of demographic assimilation, increasingly gain in importance as well.

This paper contributes to the literature on immigrant fertility assimilation, applying a count data estimation framework. Since the early contribution of BenPorath (1973) the literature on immigrant fertility has been debating whether immigrant fertility adjustment should be explained in a framework of fertility assimilation or in a model of fertility disruption. The assimilation model predicts that immigrant fertility converges to native levels, whereas the disruption model predicts increasing fertility following the disruptive effect of migration itself. With rising population shares of immigrants in western countries, ${ }^{3}$ and given ongoing debates of appropriate immigration policies, this is an important issue to investigate. Also, immigrant fertility has direct implications for the labor market involvement of the first generation, and - due to tradeoffs between the demand for child quantity and child quality - indirect effects on the human capital of second generation immigrants.

While almost all fertility adjustment studies investigate the case of immigrants to the United States (using decennial census data) this analysis focuses on migration to Europe. The selection and attraction mechanisms causing migration to Europe may differ considerably from those relevant for the United States, and may affect subsequent immigrant behavior.

In the literature on immigrant fertility adjustment over the duration of stay in the destination country it is accepted that duration and immigration year effects cannot be separately identified on the basis of cross-section data. We argue that the fertility literature, which unanimously controls for years since migration, has applied an inappropriate duration measure: When one is interested in fertility outcomes it is not the total duration of stay which should affect the number of births but the duration of stay in the receiving country which occurs during a woman's reproductive phase. In other words, whether a woman who migrated at age 35 has been in the country for 10 or 20 years will hardly make a difference

\footnotetext{
${ }^{1}$ See e.g. Schmidt 1995, Bauer and Zimmermann 1997, Schoeni 1998, or Chiswick et al. 1997.

${ }^{2}$ See e.g. Baker and Benjamin 1995, Hu 1998, Borjas and Hilton 1996, Riphahn 1998.

${ }^{3}$ The population share of immigrants in Germany grew from 1 percent in the 1950s to about 10 percent today; similarly, immigrants made up more than 10 percent of the 1990 population in countries such as Canada, Australia, or France (Segal 1993).
} 
for her completed fertility. What matters is the number of fertile years spent in the receiving country. This issue has been overlooked in the existing literature on fertility. An interesting consequence of this correction in variable definitions is that now cross-section data are sufficient to separately identify the effects of the number of fertile years in the host country and the year of immigration.

The paper proceeds as follows: After a discussion of the literature on models of immigrant fertility adjustment and a review of past findings in section two, we provide a brief description of our data, which are taken from the German Socioeconomic Panel (GSOEP). Section three additionally describes our model specification and estimation method. The results are discussed and interpreted in part four of the paper, before we conclude in section five.

\section{The Assimilation of Immigrant Fertility}

While many studies have analysed immigrant fertility adjustments, few justify their hypotheses using economic arguments. This is surprising because the economic theory of fertility provides convincing rationales for fertility adjustments after migration (for a survey see Hotz et al. 1997). Couples' demand for children can be modelled as a function of prices and income (Becker 1981): Among the relevant prices are the (potential) wage of the wife, which is frequently approximated by her human capital, the cost of child care, and the cost of fertility regulation. Husbands' earnings are the source of income effects. The model predicts that the demand for children declines if the opportunity cost of the wife's time, her potential wage, increases. Thus one reason for fertility adjustment after migration may be that potential wages in the destination country differ from women's earnings potential at home. The effects of husbands' income on fertility demand predicted by theory are ambiguous. On the one hand a higher income may increase the demand for child quantity, because the costs of children become affordable. On the other hand higher incomes increase the demand for child quality. Child quality raises the cost per child and thus justifies a negative correlation between income and the demand for children. Again, with different incomes in the origin and host countries, couples may adjust their fertility plans after migration.

This demand focused model of fertility ('Chicago-Columbia model') contrasts with the 'Pennsylvania' model, which also considers supply side factors of fertility determination, in particular a couples' fecundity and the cost of fertility regulation (e.g. Easterlin 1987, or Rosenzweig and Schultz 1985). This perspective provides another justification for the adjustment of immigrant fertility from origin to destination country levels: not only may potential incomes converge to 
the receiving country's standards, also cost and availability of contraception may differ from those in the country of origin.

Thus economic fertility theory yields three immediate arguments for fertility adjustments of immigrants: Changes in female wages, in male incomes, and the price of fertility regulation. The relevant demographic and economic literature, ${ }^{4}$ however, has focused on a separate line of argument in the analysis of immigrant behavior, and juxtaposes two models of fertility adjustment neglecting the arguments presented above.

The assimilation model suggests that couples, who migrate from a high fertility country to a low fertility country, initially follow traditional high fertility patterns, and over time adjust to the lower fertility in the destination country. Therefore it is hypothesized that the difference in completed fertility between natives and immigrants falls, the earlier in a woman's reproductive career migration to the destination country occurs. In constrast, the disruption model stresses that migration itself causes an initial drop in couples' fertility and that, subsequently, fertility will rise again. This model does not explain the level of initial or final immigrant fertility relative to the native population, but argues in terms of the direction of adjustments in period-specific - though not necessarily completed - fertility.

The two models lead to different conclusions with respect to two aspects of immigrant fertility: First, they differ with respect to the direction of short-term fertility adjustment. The assimilation model considers a slow decline in fertility and the disruption model expects an increase in fertility after the disruptive migration event. Second, the migration effect on completed fertility may differ in the two scenarios: Since in the assimilation framework migrants generally have above native level fertility until assimilation is completed, they will have higher levels of completed fertility. This "excess fertility" beyond the native level should decline the more of its fertile years a couple spent in the receiving country (see Figure 1).

The pattern of completed fertility likely differs in the case of the disruption model. Here at least three scenarios are possible, which are depicted in Figure 2. First, if - as some U.S. studies suggest (e.g. Jasso and Rosenzweig 1990) - immigrant fertility catches up after a temporary disruption, then completed fertility rates remain unaffected by the migration event and stay at the home country level (scenario A in Figure 2). Second, couples may never be able to fully catch up for the births lost due to the disruptive migration event. If the disruption effect in terms of the number of lost births is constant across all age groups, it causes a parallel downward shift in completed fertility, independent

\footnotetext{
${ }^{4}$ See e.g. Blau 1992, Schoorl 1990, Gorwaney et al. 1990, Kahn 1994, or Ford 1990.
} 
of the number of fertile years a woman spent in Germany (scenario B in Figure 2 ). Third, if couples do not catch up and the number of lost births is highest if migration occurred during the peak years of age-specific fertility, we may observe a U-shaped curve of completed fertility, when plotted against the fertile years spent abroad (scenario C in Figure 2): Disruption causes smaller losses in the years before and after peak age-specific fertility disruption than in the period of peak fertility, which generally lies between ages 20 and $30 .^{5}$ In neither scenario do we expect to see a decline in completed fertility as a function of the time spent in the receiving country.

Therefore a test between the assimilation and disruption model has to evaluate first the total difference in cumulative fertility for natives and immigrants. If immigrants from high fertility countries have below native level cumulative fertility the assimilation model can be rejected. Second, the direction of fertility adjustment can be investigated. If cumulative fertility falls over the entire range of fertile years spent in Germany this is suggestive of assimilation effects. If we observe completed fertility to be constant over the range of fertile years in Germany, we can reject the assimilation hypothesis. While it would be interesting to compare the relative impacts of the assimilation and disruption effects in detail, data limitations force us to evaluate the overall effect of migration on completed fertility.

Generally it appears that the literature on the fertility adjustment of immigrants supports the disruption model more than the assimilation explanation. Comparing observed fertility rates over the last decades (available studies use data from the 1960, 1970, and 1980 census) e.g. Blau (1992) and Jasso and Rosenzweig (1990) are careful to control for the effects of declining fertility in the native U.S. reference population as well as the effect of a changing composition of immigrant origin countries.

Besides the assimilation vs. disruption issue, the literature explicitly analyses the additional effects of (1) different countries of origin, (2) self-selection among immigrants, and (3) emigration bias. Both, Blau (1992) and Jasso and Rosenzweig (1990) find that immigrants from high fertility source countries have higher fertility in the destination country and Kahn (1988) shows the pervading influence of home country fertility. Secondly, relative to their home country population self-selected migrants are more prone to undertake long-term (e.g. human-capital) investments and to have low fertility rates. Blau (1992) shows that immigrant women are among the best educated in their native countries, which indicates high opportunity costs of child bearing. She also provides evidence that immigrants have higher tastes for child quality than natives, suggesting

\footnotetext{
${ }^{5}$ In the early 1980s age-specific fertility peaked in the agegroup 20-24 in Greece and former Yugoslavia, and in the agegroup 25-29 in Italy and Spain (UN Demographic Yearbook 1991).
} 
low fertility in the destination country. This taste for child quality is confirmed by Jasso and Rosenzweig (1990) who show that immigrants school their children at a higher rate than natives. Finally, these authors point out that selective emigration of immigrants may cause an upward bias in measured immigrant fertility, since couples with many children are less likely to return to their home country.

Both, Blau (1992) and Jasso and Rosenzweig (1990), conclude that their evidence is consistent with the model of fertility disruption. They do not find assimilation to destination country fertility levels but show that after initially low birth rates immigrants added to their family sizes at faster rates than the native population. This finding is confirmed by Ford (1990) and Kahn (1994). Only Gorwaney et al. (1990) detect disruption effects for immigrants from developed countries but conclude in favor of the assimilation model for immigrants from developing countries.

All of these studies use data from United States (U.S.) censuses and build their analyses on the results of cross-tabulations and least squares regressions. None of the papers discusses whether the period of residence in the United States is the appropriate variable to describe immigrants' exposure to U.S. culture and labor markets for the purpose of describing its effects on fertility. Also, none of these studies chose the count data estimation approach, which is compatible with the positive integer valued outcome measure. Since King (1988) we know that least squares regression may yield inconsistent estimates if applied to count data outcomes. Therefore our analysis extends the existing literature in a number of important dimensions.

While we are not aware of past studies on immigrant fertility adjustment for Germany, a related literature analyses the fertility effect of German unification. Between 1989 and 1994 East German births fell by sixty percent. Conrad et al. (1996) and Lechner (1998) investigate the East German fertility transition and conclude that fertility takes on West German patterns. They suggest that the strong fertility disruption immediately after unification was only a temporary adjustment phenomenon: Fertility rates of older women suddenly dropped, since their completed fertility already exceeded Western patterns, and young women postponed births adhering to the West German pattern of late first births. Here a situation which looked like disruption masks the first signs of assimilation.

From the above discussion we derive five hypotheses which we test below:

(H1) The higher a woman's (potential) labor market income, the lower her completed fertility.

(H2) The assimilation hypothesis suggests that immigrants' completed fertility exceeds that of natives and that it falls with the number of fertile years 
spent in Germany.

(H3) The disruption hypothesis with catch-up suggests that immigrants' completed fertility does not vary over the number of fertile years spent in Germany.

(H4) The disruption hypothesis without catch-up suggests that immigrants' completed fertility takes on a U-shaped form over the number of fertile years spent in Germany.

(H5) Country of origin fertility differences are reflected in immigrant fertility.

\section{Data, Specification, and Estimation Method}

Our data are taken from the 1996 wave of the German Socioeconomic Panel (GSOEP). The GSOEP is a representative survey of households and individuals, administered annually since 1984. It oversamples the guest-worker population in Germany with Turkish, Spanish, Greek, Italian and what was Yugoslavian origin. The original 1984 sample consisted of about 4,500 native German and 1,400 foreign households with a total of more than 12,000 respondents.

Since guest-worker immigration to Germany commenced in the late 1950s, ${ }^{6}$ some of the foreign respondents of the 1996 GSOEP survey are already second generation immigrants, and born in Germany. To generate a homogenous sample we consider only those female respondents, who are either of German nationality and born in Germany (our native sample), or of foreign nationality and born abroad (the immigrant sample). Additionally, we restrict attention to immigrants from the five oversampled sending countries. Since we are interested only in completed fertility, we selected observations of women age 40 and above, and coded the number of their past births as our dependent variable. After omitting observations with missing values on core variables (such as the immigration year or schooling indicators) our native sample consisted of 1,718 and the immigrant sample of 375 observations.

In the immigrant sample one third of the women are Turkish, 28 percent originated in former Yugoslavia, 17 percent each came from Greece and Italy, and 6.5 percent are of Spanish descent. Table 1 describes the fertility developments in these countries and in Germany over the last seven decades. It is apparent, first, that German fertility up to the 1980s has been below that of the five sending countries. Second, fertility in Turkey has always been above that of any other country. Third, in all countries fertility declines over time and, finally, since the

\footnotetext{
${ }^{6}$ The first guest-worker treaty was signed in 1955 with Italy.
} 
mid eighties fertility in Greece, Italy, Spain, and Germany has converged at a low level.

These trends are also apparent in the distribution of the dependent variable of our analysis. Table 2 describes our dependent and explanatory variables by subsample. German completed fertility with 1.93 births per woman is below that of the immigrant population with an average of 2.89 births. However, this average across immigrant groups hides substantial nationality differences: The average number of 3.8 births for Turkish women far exceeds the immigrant average. Next in rank are women of Italian and Spanish nationality with 2.8 and 2.5 births, respectively. The women from Greece and from former Yugoslavia in our sample average 2.3 births (these figures are not presented in Table 2).

Figure 3 gives an impression of the correlation in our data between completed fertility and the number of fertile years an immigrant woman spent in Germany. The overall negative trend is obvious and even clearer when we consider average completed fertility as summarized by fertile year groups in Table 3: The reference fertility of women who spent their entire fertile period abroad (first row) is on average 3.8 children. Women who spent between one and five years of their fertile period in Germany average 3.22 births, those who spent almost all their fertile time in Germany average 2.33 births, much closer to the native average of 1.93 . Table 3 presents average fertility also by the standard measure of duration in this literature, years since migration. The tabulation by fertile years in Germany shows a smoother development in the average number of births than years since migration, which confounds age and immigration year effects. The high average number of births in the 6 - 10 year group of fertile years in Germany (3.63 births) arises in part due to the effect of two Turkish outlier observations with 10 births in this group. ${ }^{7}$ The separate presentation of completed immigrant fertility by nationality groups (see the last four columns of Table 3) confirms first that the aggregate findings of declining completed fertility over an increasing number of fertile years in Germany are not due to composition effects of Turkish and nonTurkish immigrants. Second, it shows that the high average number of births in the 6 - 10 fertile years group exists indeed only for immigrants of Turkish nationality and does not represent a common feature for all immigrants.

When comparing the descriptive statistics of the explanatory variables in Table 2 across the two samples we notice a number of differences. First, the average age of the German sample is clearly above that of the immigrant population. Further, immigrant women have on average about two years less education than their native counterparts. This difference is more strongly reflected in the distribution of schooling degrees, where about half of all immigrant women fall in

\footnotetext{
${ }^{7}$ Omission of these two observations leads to an average of 3.44 births in this group for the overall sample and of 5.07 in the Turks-only column.
} 
the omitted category of no schooling degree compared to less than one percent of the natives. Whereas only 38 percent of all native females in our sample have no vocational degree, this holds for 85 percent of the immigrant women. ${ }^{8}$ Based on female opportunity cost of child bearing, these statistics suggest that immigrant families are likely to have higher rates of fertility than natives. The variables describing the women's religious affiliation suggest that natives are much more likely to be either catholic or protestant (jointly 90 percent of the native sample). In the immigrant sample there are almost no protestants and about one third is in the "other" category, which mostly comprises muslims.

Based on the discussion in section 2, the specification of our empirical model for completed fertility considers four groups of explanatory variables. First, we control for overall demographic effects consisting first of a woman's age, to account for cohort differences in fertility (cf. Table 1). To control for her health the specification controls for her handicap status, assuming that health in 1996 is indicative of health during the reproductive phase. The health effect is not clear a priori: Through biological mechanisms poor health may reduce fertility, but then reduced earnings potentials of those in poor health reduce the opportunity costs of fertility. ${ }^{9}$ In order to test whether the number of years a woman spent in the destination country prior to her fertile period affects her fertility we additionally control for pre-fertile-years spent in Germany before age 15. While it is possible in principle to control for the year of immigration in addition to our model, we chose not to introduce this variable in order to strengthen the identification of age and assimilation effects. ${ }^{10}$

Second, we approximate the effect a woman's earnings potential, using as control variables years of education, schooling and vocational training degree indicators, where 'no degree' is the omitted category, and an indicator of whether she speaks German well. Third, following the fertility literature we control for the effect of religious affiliation on fertility (e.g. Winkelmann, 1995).

Finally, we control for women's immigrant status: In the 'immigrant model' we consider only an indicator variable for whether the woman is an immigrant.

\footnotetext{
${ }^{8}$ The low probability of having exactly the mandatory schooling degree seems surprising and might be due to coding problems with foreign degrees. Since we tested for but did not find statistically significant differences in the effect of these measures on completed fertility for the native and immigrant sample, we are confident that the potential measurement error does not bias our results in important ways.

${ }^{9}$ Clearly, the 1996 health measure is a poor approximation of a woman's health during her fertile period. However, unfortunately a more accurate health indicator is not available.

${ }^{10}$ Whereas the standard assimilation measure 'years since migration' imposes a limitation on cross-section estimation through the linear relationship: immigration year + years since migration $=$ survey year, the relationship in our specification provides more degrees of freedom. In our case the restriction is: immigration year + fertile years in Germany + (age - 40) + prefertile-years spent in Germany - post-fertile-years in home country = year of survey.
} 
In a 'nationality model' we evaluate independent nationality effects for the source countries represented in our sample. The effect of fertile years in Germany on completed fertility is captured in three alternative specifications: In our baseline immigrant model we control for fertile year effects fitting a fourth order polynomial. Then we lift the parametric restriction on the effect of fertile-yearsin-Germany and instead control for a set of indicator variables. The third model drops the underlying assumption that different nationalities have identical effects and instead estimates separate third order polynomials for each nationality group.

Given that the dependent variable of our analysis always takes on positive, integer values, count data models are the natural choice for the regression. A problem which we face upon application of the standard Poisson model is that as in other studies of completed fertility (see e.g. Winkelmann and Zimmermann 1994) - the equidispersion assumption which underlies this estimation approach, is violated in our data. We applied regression-based tests of the equidispersion hypothesis (Cameron and Trivedi 1990) and find clear evidence of underdispersion, i.e. the conditional mean exceeds the conditional variance. In such a situation the Poisson-ML estimator overestimates the standard errors.

To solve this problem, different approaches have been proposed, which are based on special distributions allowing for underdispersion and estimated via maximum likelihood. Examples are the generalized event count model (Winkelmann and Zimmermann 1994) the generalized poisson model (Consul 1989) or the Gamma count data model (Winkelmann 1995). In contrast and following McCullagh and Nelder (1989), we adapt a quasi-likelihood approach to generalize the Poisson model. The method is more general than the above in that it relies directly on the specification of the first two (conditional) moments,

$$
\begin{aligned}
E\left[y_{i} \mid X_{i}\right] & =\lambda_{i}=\exp \left(X_{i} \beta\right) \\
V\left[y_{i} \mid X_{i}\right] & =\phi * \lambda_{i}, .
\end{aligned}
$$

where $y_{i}$ and $X_{i}$ are the univariate dependent count variable and the vector of regressors respectively, $\beta$ is the parameter of interest and $\phi$ is an additional dispersion parameter. On the basis of these two moments a quasi-likelihood estimating equation is derived which is solved to get estimates $\hat{\beta}$ of $\beta$. It is important to mention, that these estimates do not depend on $\phi$. In a second step estimates for $\phi$ are obtained as moment estimators

$$
\hat{\phi}=\frac{1}{n} \sum_{i} \frac{\left(y_{i}-\exp \left(X_{i} \hat{\beta}\right)\right)^{2}}{\exp \left(X_{i} \hat{\beta}\right)} .
$$

With $\hat{\phi}$ in hand reliable standard errors of $\hat{\beta}$ can be calculated (see McCullagh and Nelder 1989). Section four now discusses our estimation results. 


\section{Estimation Results}

This section interprets the estimation results with respect to the hypotheses formulated in section 2 above. Table 4 presents the estimation results. Column (1) presents the immigrant model which controls for an immigrant indicator, and a fourth order polynomial of the number of fertile years an immigrant woman spent in Germany. Column (2) presents the immigrant model with a categorical representation of the fertile-years-in-Germany effect and the last column describes the estimation results controlling for nationality differences. The data for our native and immigrant samples are pooled in the estimations. Therefore the immigrant and nationality indicators are to be interpreted relative to the overall average. In preliminary estimations we tested for differences in coefficient effects between the native and immigrant samples. These tests yielded statistically significant differences only for variables describing religious affiliation. Hence these interaction effects are considered in the final specifications.

For every of the final specifications we performed an underdispersion test (Cameron and Trivedi 1990) which always rejected the hypothesis of equidispersion at the 1 percent significance level. Since the Poisson model is not appropriate for our data we only report the results from the quasi-likelihood estimation. As in the framework of Poisson regressions, the estimated coefficients can be interpreted as semi-elasticities. Thus e.g. a one unit increase in age causes here an increase in completed fertility by half a percent. Given the scaling of the age variable, the one unit change represents a ten year difference in birth cohorts. Going back to Table 1, which indicated continuously falling fertility rates over time, the estimated age effect, though not significantly different from zero, corresponds to expectations. The effects of a handicap and of pre-fertile years spent in Germany on completed fertility are very small and statistically insignificantly different from zero. ${ }^{11}$

The coefficients of the six variables describing women's human capital should be interpreted in view of hypothesis $\mathrm{H} 1$, which proposed a negative correlation between a woman's (potential) income and her completed fertility. ${ }^{12}$ The hypothesis is confirmed by the estimated coefficients: We find a statistically significant

\footnotetext{
${ }^{11}$ Most likely this result is due to the very small number of women who spent pre-fertile years in Germany. As an alternative to our assimilation measure we examined whether the sum of pre-fertile and fertile years in the host country yields different results, which was not the case.

${ }^{12}$ While some might argue that the educational attainment of a woman is determined by similar mechanisms as completed fertility and therefore endogenous, we refer to the findings of Heckman et al. (1985) that even concurrent school attendance is not endogenous to observed period-specific fertility. In addition the completed fertility outcome is observable only after age 40 while typical educational decisions are taken prior to age 20 . This limits any potential endogeneity.
} 
decline in completed fertility by 3.8 percent for every year of schooling. Whereas the indicators of schooling degree are not statistically significant, having a vocational degree is correlated with lower completed fertility. The only surprising finding is that women with only an apprenticeship degree reduced their births by more than those with an advanced degree. Also confirming H1, those immigrant women who speak German well have significantly fewer births than those with limited language capability. The six coefficients of the human capital variables are jointly statistically significant in each of the three estimated specifications.

The controls for religious affiliation are statistically highly significant and indicate for the native sample that catholics and protestants have significantly more births than those of other christian or no religious affiliation. Some immigrant effects differ significantly from those for natives such that the net effects of being catholic or protestant on completed fertility among immigrants is negative and that of being of another religion (mostly reflecting the muslim religion) maintains an overall positive effect, even though it is not statistically significant.

We are most interested in the effects of fertile years in Germany on completed fertility. Since the coefficients of the fourth order polynomial, which are jointly highly significant, are difficult to interpret by inspection, we plotted the curvature of this effect including that of the immigrant indicator in Figure 4. The solid line represents the fertile years effect, the dashed lines are 90 percent pointwise confidence bands. Figure 4 contains three interpretable pieces of information: First, over the entire range of fertile years that are possibly spent in Germany the immigrant effect is positive. Based on this we cannot reject the assimilation hypothesis (H2) out of hand. Second, the impact of being an immigrant in Germany (conditional on the other covariates) falls almost over the entire range of fertile years. Finally, immigrant status is correlated with a statistically significant positive effect on completed fertility for all immigrants independent of their age at immigration.

In addition, the graph contains two surprising features. The first is the increase in completed fertility between zero and five fertile years, and the second is the increasing curvature after the twentyfirst fertile year. The first feature may in part be due to the presence of two outlier observations which we already encountered in the discussion of Table 3. The second feature may well be due to the parameterization of the fertile year effect. Less than three percent of the immigrant sample have 23 or more fertile years in Germany, a fact which is responsible for the large confidence interval around the curve at this point. To evaluate the effect of parametric functional form assumptions we reestimated the model in column 1 of Table 4 dropping the observations with more than 20 fertile years in Germany. The results are plotted in Figure 5 and suggest that the estimated functional form causes a steep increase in the effect after 20 fertile years, 
even if there are no observations in this value range whatsoever. This finding lends support to the hypothesis that the increase in the curvature at the upper tail of fertile years in Germany is due to functional form, rather than to higher completed fertility.

A different test of this hypothesis can be derived from the second specification, which instead of the fourth order polynomial controls for a set of categorical variables (column 2 in Table 4). By inspection we see that the coefficients of the other explanatory variables are robust to this change in the specification. The seven indicators of fertile years spent in Germany are individually as well as jointly statistically significant and positive. Figure 6 plots the estimated effects of fertile years spent in Germany by the specifications presented in columns (1) and (2) of Table 4. While the increase in the step function of categorical effects after the sixth fertile year in Germany is difficult to explain within either of our hypotheses we find that the second surprising feature of the fourth order polynomial representation, the increase in completed fertility after year 21 , disappears in the results of specification (2).

In order to evaluate hypotheses $\mathrm{H} 2$ through $\mathrm{H} 4$ posed in section 2 we performed two types of tests. Based on the polynomial specification we tested the hypothesis that a higher number of fertile years spent in Germany yields the same completed fertility compared to zero fertile years spent in Germany. Confirming the depiction in Figure 4 we were able to reject this hypothesis at the ten percent significance level up for 15 through 25 fertile years spent in Germany. Based on the categorical specification we tested the hypothesis that the coefficient on a higher number of fertile years spent in Germany yields the same effect as that of zero fertile years spent in Germany. This hypothesis was rejected at the ten percent significance level for the indicators reflecting 14 through 25 fertile years spent in Germany.

With respect to our hypotheses formulated above we conclude first that immigrants' completed fertility exceeds that of natives. Second, we find that those who spent more than 15 of their fertile years in Germany, i.e. those who migrate prior to age 26, have significantly fewer births than those coming later in life. So overall H2 cannot be rejected, while the hypothesis of a disruption effect with complete catch-up (H3) is rejected.

Hypothesis $\mathrm{H} 4$ proposes a U-shaped pattern in the curvature depicted in Figures 4 through 6 . While we cannot reject this hypothesis based on a statistical test, the support for it is limited, and non-existent if we base our judgement on the categorical specification. Even though the analysis does not permit conclusions regarding the existence of disruption effects, it is apparent that cumulative fertility approaches that of the native population "from above", the longer a woman's exposure in Germany during her fertile period. Therefore we conclude with re- 
spect to hypothesis four (H4) above that our evidence favors the assimilation model of fertility adjustment for the sample of immigrants to Germany.

In order to test hypothesis H5, we estimated specification (3) in Table 4, which controlled for nationality-specific third order polynomials of the fertile year effect. While some of the estimated coefficients are sensitive to this change in the specification, the overall conclusions regarding other explanatory variables outlined above do not change. In Table 4 we present the first order nationality effects, which however can only be interpreted in conjunction with the jointly estimated interaction effects for religion. To simplify the interpretation we plotted the nationality-specific fertile year effect conditional on these interaction terms in Figures 7 through 11.

Inspection of these figures yields that the fertility adjustment effect across fertile years in Germany follows different transition paths for the different origin countries, thus supporting hypothesis five (H5) above. We find significant deviations from native German completed fertility in each of these depictions, even though the exact curvatures vary across nationalities. The smallest absolute deviation in completed fertility relative to the native sample is found for immigrants of Greek nationality in Figure 10. This graph suggests an almost flat completed fertility line which suggests no assimilation effects for this subsample. The graphs which appear to be most supportive of assimilation effects are those describing the fertility adjustments of the Italian and Spanish immigrant populations in Figures 8 and 9. In contrast, immigrants from former Yugoslavia (Figure 11) almost show a weak U-shaped adjustment and those from Turkey (Figure 7) do not match any of the posed hypotheses. We do not wish to stress these patterns too much, as the parameters are estimated on small samples with e.g. only 24 observations for the case of Spain, or about 60 for Italy and Greece.

In order to determine, whether there are statistically significant countryspecific effects we estimated a version of specification (3), where the controls for the interaction effects for Turkish nationals were replaced with overall immigrant effects. ${ }^{13}$ Based on these results we were able to test the hypothesis that the effects for single nationalities are identical with the overall immigrant effect. The results yielded significant differences for immigrants from Italy and from former Yugoslavia. Therefore we cannot reject hypothesis H5, which states that there are significant country of origin differences in fertility and fertility assimilation.

\footnotetext{
${ }^{13}$ The results are available from authors upon request.
} 


\section{Conclusions}

This study contributes to the literature on fertility adjustment in a number of ways. First, we test the assimilation hypothesis for the case of immigration to Germany. Given that almost the entire literature focuses on the United States and applies the same U.S. population census data, new insights are gained by widenening the perspective to the scenario of European immigration. Second, we suggest that a measurement error has pervaded the existing literature. Since the researcher is interested in the effects of living in the destination country on immigrant behavior, years since migration has been utilized as the relevant duration measure. We argue that this is inappropriate for the issue of fertility, where one should be interested in the number of fertile years spent in the destination country. Third, in contrast to former studies, which applied least squares estimators even though the relevant dependent variable is a count, this study applies the appropriate count data estimation technique.

Contrary to the results for U.S. immigrants, we find evidence supporting the assimilation model of immigrant fertility adjustment. The assimilation model suggests that immigrant fertility is initially above the native level and over time converges to that of the native population. In the United States recent immigrants entered with very low fertility rates but then added to their family sizes at rates beyond those of natives (e.g. Blau 1992, Jasso and Rosenzweig 1990). The increase in immigrant fertility rates over the duration of stay in the host country is taken as evidence for the disruption and against the assimilation model of fertility adjustment.

Our results suggest that immigrants to Germany enter the country with fertility rates above native levels and that their completed fertility falls the more of their fertile time they spend in Germany. This finding corresponds to the predictions of the assimilation model (H2). We reject the hypothesis that immigrant fertility follows a disruption model with complete catch-up (H3), and have no evidence supporting a disruption effect without complete catch-up (H4). Beyond the fertility adjustment effect, we confirm the prediction of the standard economic model regarding the negative opportunity cost effect of female human capital on total fertility outcomes (H1) and find statistically significant differences in fertility assimilation by country of origin ( $\mathrm{H} 5)$.

We can only speculate as to why prior U.S. studies did not find assimilation effects. If assimilation behavior is in fact driven by economic variables, then the fertility convergence result which we find for Germany, must be explained by the differences in fertility determinants (wages, incomes and cost of contraception) between the countries of origin and destination. These differences must be more pervading for immigrants to Germany, than for immigrants to the United States. 
In other words, the difference between the Turkish rural standard of living and that in German towns must differ by more than prices and incomes in, say, northern Mexico and southern Texas. To the degree that German society is more homogenous than the American society this argument is plausible. ${ }^{14} \mathrm{~A}$ more concrete example of such differences results if we argue that children function as an old-age insurance device. Since guaranteed social security incomes in the United States typically exceed those of immigrants' countries of origin by less than those in Germany, this might explain the different adjustment patterns.

However, the findings may in part be due to the different data and estimation methods. While the U.S. studies use decennially available census evidence we apply a representative micro-level dataset. Our estimation method accounted for the discrete nature of the outcome variable and for its underdispersion. It proofed to be highly appropriate for the research question and we are confident that our results are reliable and provide an interesting addition to the literature on immigrant fertility adjustment.

\footnotetext{
${ }^{14}$ Interestingly, the analysis of Dutch immigrants by Schoorl (1990) also yields an assimilation result.
} 


\section{References}

Baker M Benjamin D (1995) The Receipt of Transfer Payments by Immigrants to Canada. Journal of Human Resources 30(4): 650-676

Bauer T Zimmermann KF (1997) Unemployment and Wages of Ethnic Germans. Quarterly Review of Economics and Finance 37(0) special issue: $361-377$

Becker GS (1981) A Treatise on the Family, Harvard University Press, Cambridge Mass. and London

Ben-Porath Y (1973) Economic Analysis of Fertility in Israel: Point and Counterpoint. Journal of Political Economy 81(2): 202-233

Blau FD (1992) The Fertility of Immigrant Women: Evidence from HighFertility Source Countries. In: George JB Freeman RB (eds) Immigration and the Work Force: Economic Consequences for the United States and Source Areas The University of Chicago Press. Chicago and London: 93-133

Borjas GJ Hilton L (1996) Immigration and the Welfare State: Immigrant Participation in Means-Tested Entitlement Programs. Quarterly Journal of Economics 111(2): 575-604

Cameron AC Trivedi PK (1990) Regression-Based Tests for Overdispersion in the Poisson Model. Journal of Econometrics 46: 347-364

Chiswick BR Cohen Y Zach T (1997) The Labor Market Status of Immigrants: Effects of the Unemployment Rate at Arrival and Duration of Residence. Industrial and Labor Relations Review 50(2): 289-303

Conrad C Lechner M Werner W (1996) East German Fertility After Unification: Crisis or Adaptation. Population and Development Review 22(2): 331-358

Consul P C (1989) Generalized Poisson Distributions: Properties and Applications, Marcel Dekker, New York

Easterlin RA (1987) Fertility, in: Eatwell J Milgate M Newman P (eds) The New Palgrave. A Dictionary of Economics, The Macmillan Press Ltd., London: 302-308

Ford K (1990) Duration of Residence in the United States and the Fertility of U.S. Immigrants. International Migration Review, 24 1(89): 34-68 
Gorwaney N Van Arsdol MD Heer DM Schuerman LA (1990) Variations in Fertility and Earnings Patterns among Immigrants in the United States, 19701980: Assimilation or Disruption? International Migration 28: 451-475

Hotz VJ Klerman JA Willis RJ (1997) The Economics of Fertility in Developed Countries. In: Rosenzweig MR Stark O (eds), Handbook of Population and Family Economics Volume 1a, Elsevier Publishers, North-Holland: 275-347

Hu W (1998) Elderly Immigrants on Welfare. Journal Human Resources 33(3): 711-741

Jasso G Rosenzweig MR (1990) The Immigrant's Legacy: Investing in the Next Generation. In: Jasso G Rosenzweig MR (eds), The New Chosen People: Immigrants in th United States Russell Sage Foundation, New York: 382410

Kahn JR (1988) Immigrant Selectivity and Fertility Adaption in the United States, Social Forces 67(1): 108-128

Kahn JR (1994) Immigrant and Native Fertility During the 1980s: Adaptation and Expectations for the Future. International Migration Review 28(3): $501-519$

King G (1988) Statistical Models for Political Science Event Counts: Bias in Conventional Procedures and Evidence for the Exponential Poisson Regression Model. American Journal of Political Science, 32: 838-862

Lechner M (1998) Eine Empirische Analyse des Geburtenrückgangs in den Neuen Bundesländern aus der Sicht der Neoklassischen Bevölkerungs" okonomie. Zeitschrift für Wirtschafts- und Sozialwissenschaften 118(3): 463-488

McCullagh P Nelder JA (1989) Generalized Linear Models, 2nd ed. Chapman and Hall, New York

Riphahn RT (1998) Immigrant Participation in the German Welfare Program, Finanzarchiv 55(2): 163-185.

Rosenzweig MR Schultz TP (1985) The Demand for and Supply of Births: Fertility and its Life Cycle Consequences. American Economic Review 75(5): 992-105

Schmidt CM (1995) The Earnings Performance of Migrants in the German Labor Market. mimeo

Schoeni RF (1998) Labor Market Assimilation of Immigrant Women. Industrial and Labor Relations Review 51: 483-504 
Schoorl JJ (1990) Fertility Adaptation of Turkish and Moroccan Women in the Netherlands. International Migration 28: 477-495

Segal A (1993) An Atlas of International Migration, Hans Zell Publishers, London

United Nations (1992) Demographic Yearbook 1991, 43rd issue, United Nations Publication, New York.

Winkelmann R (1995) Duration Dependence and Dispersion in Count-Data Models. Journal of Business and Economic Statistics 13: 467-474

Winkelmann R Zimmermann KF (1994) Count Data Models for Demographic Data. Mathematical Population Studies 4: 205-221 


\section{Tables and Figures}

Table 1: International Fertility Rates

\begin{tabular}{|c|c|c|c|c|c|c|}
\hline Year & West Germany & Greece & Italy & Spain & Turkey & Ex-Yugoslavia \\
\hline \multicolumn{7}{|c|}{ a) Crude Fertility Rates } \\
\hline 1930 & 18 & 31 & 27 & 28 & n.a. & 32 \\
\hline 1940 & 20 & 25 & 24 & 24 & n.a. & 25 \\
\hline 1950 & 16 & 20 & 19 & 20 & n.a. & n.a. \\
\hline 1960 & 17 & 19 & 18 & 22 & 43 & 24 \\
\hline 1965 & 18 & 19 & 18 & 22 & 41 & 24 \\
\hline 1970 & 13 & 17 & 17 & 20 & 36 & 18 \\
\hline 1975 & 10 & 16 & 15 & 19 & 34 & 18 \\
\hline 1982 & 10 & 14 & 11 & 15 & 31 & 15 \\
\hline 1985 & 10 & 12 & 10 & 12 & 30 & 16 \\
\hline 1989 & 11 & 10 & 10 & 11 & 26 & 14 \\
\hline 1993 & 11 & 10 & 10 & 10 & 27 & n.a. \\
\hline \multicolumn{7}{|c|}{ b) Average Completed Fertility } \\
\hline $1970 / 75$ & 1.64 & 2.32 & 2.28 & 2.89 & 5.04 & n.a. \\
\hline $1980 / 85$ & 1.46 & 1.96 & 1.55 & 1.86 & 4.10 & n.a. \\
\hline $1990 / 95$ & 1.50 & 1.47 & 1.31 & 1.38 & 3.45 & n.a. \\
\hline $1995 / 2000$ & 1.30 & 1.40 & 1.27 & 1.23 & 3.04 & n.a. \\
\hline
\end{tabular}

Note: Crude Fertility Rates: Rounded livebirths per 1000 inhabitants; Average Completed Fertility: Hypothetical average number of births per woman based on age-specific fertility in observation period.

Source: Crude Fertility Rates-United Nations Demographic Yearbook, Federal Statistical Office Germany: Statistical Yearbook, World Bank: World Development Report; Average Completed Fertility - Federal Statistical Office Germany: Statistical Yearbook for Foreign Countries 1998. 
Table 2: Descriptive Statistics

\begin{tabular}{|c|c|c|c|}
\hline Variable & Description & $\begin{array}{l}\text { Native } \\
\text { Sample }\end{array}$ & $\begin{array}{r}\text { Immigrant } \\
\text { Sample }\end{array}$ \\
\hline NumBirth & Number of births & $\begin{array}{r}1.931 \\
(1.353)\end{array}$ & $\begin{array}{r}2.893 \\
(1.782)\end{array}$ \\
\hline Age & Woman's age $\left(* 10^{-1}\right)$ & $\begin{array}{r}5.981 \\
(1.243)\end{array}$ & $\begin{array}{r}5.243 \\
(0.775)\end{array}$ \\
\hline Pre-fertile-years & $\begin{array}{l}\text { Number of years spent in Germany prior to } \\
\text { age } 15\end{array}$ & $\begin{array}{r}0 \\
(0)\end{array}$ & $\begin{array}{r}0.024 \\
(0.416)\end{array}$ \\
\hline Handicap & $0 / 1$ woman is handicapped & $\begin{array}{r}0.185 \\
(0.388)\end{array}$ & $\begin{array}{r}0.107 \\
(0.309)\end{array}$ \\
\hline Schooling & Years of schooling $\left(* 10^{-1}\right)$ & $\begin{array}{r}1.074 \\
(0.209)\end{array}$ & $\begin{array}{r}0.885 \\
(0.196)\end{array}$ \\
\hline S_Mandatory & 0/1 Woman completed mandatory schooling & $\begin{array}{r}0.695 \\
(0.461)\end{array}$ & $\begin{array}{r}0.005 \\
(0.073)\end{array}$ \\
\hline S_Advanced & 0/1 Woman completed advanced schooling degree & $\begin{array}{r}0.299 \\
(0.458)\end{array}$ & $\begin{array}{r}0.488 \\
(0.501)\end{array}$ \\
\hline V_Apprentice & 0/1 Woman completed apprenticeship & $\begin{array}{r}0.384 \\
(0.486)\end{array}$ & $\begin{array}{r}0.077 \\
(0.268)\end{array}$ \\
\hline V_Advanced & 0/1 Woman completed advanced vocational degree & $\begin{array}{r}0.239 \\
(0.426)\end{array}$ & $\begin{array}{r}0.088 \\
(0.284)\end{array}$ \\
\hline German_spoken & $\begin{array}{l}\text { Good knowledge of spoken German } \\
\text { (coded } 0 \text { for native sample) }\end{array}$ & $\begin{array}{r}0 \\
(0)\end{array}$ & $\begin{array}{r}0.269 \\
(0.444)\end{array}$ \\
\hline Catholic & $0 / 1$ Woman is catholic & $\begin{array}{r}0.434 \\
(0.496)\end{array}$ & $\begin{array}{r}0.395 \\
(0.489)\end{array}$ \\
\hline Protestant & $0 / 1$ Woman is protestant & $\begin{array}{r}0.487 \\
(0.500)\end{array}$ & $\begin{array}{r}0.005 \\
(0.073)\end{array}$ \\
\hline Other_Religion & $0 / 1$ Woman is of non-christian religion & $\begin{array}{r}0.001 \\
(0.034)\end{array}$ & $\begin{array}{r}0.333 \\
(0.472)\end{array}$ \\
\hline Catholic*Immi & $0 / 1$ Woman is catholic and immigrant & $\begin{array}{r}0 \\
(0)\end{array}$ & $\begin{array}{r}0.395 \\
0.489)\end{array}$ \\
\hline Protestant*Immi & $0 / 1$ Woman is protestant and immigrant & $\begin{array}{r}0 \\
(0)\end{array}$ & $\begin{array}{r}0.005 \\
(0.073)\end{array}$ \\
\hline Other_Religion*Immi & $0 / 1$ Woman is non-christian and immigrant & $\begin{array}{r}0 \\
(0)\end{array}$ & $\begin{array}{r}0.333 \\
(0.472)\end{array}$ \\
\hline Immigrant & $0 / 1$ Woman is an immigrant & $\begin{array}{r}0.000 \\
(0.000)\end{array}$ & $\begin{array}{r}1.000 \\
(0.000)\end{array}$ \\
\hline N_Turkish & $0 / 1$ Woman is of Turkish Nationality & $\begin{array}{r}0 \\
(0)\end{array}$ & $\begin{array}{r}0.320 \\
(0.467)\end{array}$ \\
\hline N_Yugoslav & 0/1 Woman is of Ex-Yugoslavian Citizenship & $\begin{array}{r}0 \\
(0)\end{array}$ & $\begin{array}{r}0.280 \\
(0.450)\end{array}$ \\
\hline N_Greek & $0 / 1$ Woman is of Greek Nationality & $\begin{array}{r}0 \\
(0)\end{array}$ & $\begin{array}{r}0.165 \\
(0.372)\end{array}$ \\
\hline N_Italian & $0 / 1$ Woman is of Italian Nationality & $\begin{array}{r}0 \\
(0)\end{array}$ & $\begin{array}{r}0.171 \\
(0.377)\end{array}$ \\
\hline N_Spanish & $0 / 1$ Woman is of Spanish Nationality & $\begin{array}{r}0 \\
(0)\end{array}$ & $\begin{array}{r}0.064 \\
(0.245)\end{array}$ \\
\hline Fertile Years & $\begin{array}{l}\text { Number of fertile years spent in Germany } \\
\text { (coded } 0 \text { for native sample) }\end{array}$ & $\begin{array}{r}0 \\
(0)\end{array}$ & $\begin{array}{r}1.312 \\
(0.711)\end{array}$ \\
\hline FYG_G0 & 0 fertile years spent in Germany & $\begin{array}{r}0 \\
(0)\end{array}$ & $\begin{array}{r}0.093 \\
(0.291)\end{array}$ \\
\hline
\end{tabular}


Table 2: continued

\begin{tabular}{|c|c|c|c|}
\hline Variable & Description & $\begin{array}{r}\text { Native } \\
\text { Sample }\end{array}$ & $\begin{array}{r}\text { Immigrant } \\
\text { Sample }\end{array}$ \\
\hline FYG_G1 & $1-6$ fertile years spent in Germany & $\begin{array}{r}0 \\
(0)\end{array}$ & $\begin{array}{r}0.117 \\
(0.322)\end{array}$ \\
\hline FYG_G2 & 7-9 fertile years spent in Germany & $\begin{array}{r}0 \\
(0)\end{array}$ & $\begin{array}{r}0.101 \\
(0.302)\end{array}$ \\
\hline FYG_G3 & 10-13 fertile years spent in Germany & $\begin{array}{r}0 \\
(0)\end{array}$ & $\begin{array}{r}0.144 \\
(0.352)\end{array}$ \\
\hline FYG_G4 & $14-17$ fertile years spent in Germany & $\begin{array}{r}0 \\
(0)\end{array}$ & $\begin{array}{r}0.192 \\
(0.394)\end{array}$ \\
\hline FYG_G5 & $18-21$ fertile years spent in Germany & $\begin{array}{r}0 \\
(0)\end{array}$ & $\begin{array}{r}0.259 \\
(0.439)\end{array}$ \\
\hline FYG_G6 & $22-25$ fertile years spent in Germany & $\begin{array}{r}0 \\
(0)\end{array}$ & $\begin{array}{r}0.093 \\
(0.291)\end{array}$ \\
\hline Number $\mathrm{o}$ & & 1718 & 375 \\
\hline
\end{tabular}


Table 3: Completed Fertility by Alternative ‘Duration' Indicators

\begin{tabular}{c|cc|cc|cc|} 
& \multicolumn{2}{|c|}{ All Immigrants } & \multicolumn{2}{c|}{ Turkish } & \multicolumn{2}{c|}{ Non Turkish Immigrants } \\
& FYG & YSM & FYG & YSM & FYG & YSM \\
\hline 0 & 3.80 & n.a. & 3.14 & n.a. & 4.24 & n.a. \\
$1-5$ & 3.22 & 2.50 & 3.64 & 1.00 & 2.77 & 3.25 \\
$6-10$ & 3.63 & 6.50 & 5.41 & 4.00 & 2.31 & 7.33 \\
$11-15$ & 2.73 & 2.50 & 3.40 & 2.33 & 2.40 & 2.67 \\
$16-20$ & 2.49 & 3.59 & 3.19 & 4.33 & 2.25 & 2.63 \\
$21-25$ & 2.33 & 2.97 & 3.08 & 3.85 & 2.16 & 2.30 \\
$26-30$ & - & 2.77 & - & 4.00 & - & 2.43 \\
$31-35$ & - & 2.48 & - & 3.25 & - & 2.35 \\
\hline
\end{tabular}

Note: $F Y G=$ fertile years in Germany; $Y S M=$ years since migration;

Source: Own calculations based on German Socioeconomic Panel (GSOEP) 


\begin{tabular}{|c|c|c|c|}
\hline Variable & $\begin{array}{r}\text { Immigrant } \\
\text { Polynomial } \\
(1) \\
\end{array}$ & $\begin{array}{l}\text { Model (IM) } \\
\text { Categorical } \\
(2) \\
\end{array}$ & $\begin{array}{c}\text { Nationality Model (NM) } \\
\text { Polynomial } \\
(3) \\
\end{array}$ \\
\hline Constant & $\begin{array}{c}0.889^{* *} \\
(5.012)\end{array}$ & $\begin{array}{c}0.886^{* *} \\
(4.998)\end{array}$ & $\begin{array}{c}0.861^{* *} \\
(4.855)\end{array}$ \\
\hline Age & $\begin{array}{c}-0.005 \\
(-0.400)\end{array}$ & $\begin{array}{c}-0.006 \\
(-0.433)\end{array}$ & $\begin{array}{c}-0.006 \\
(-0.409)\end{array}$ \\
\hline Pre-fertile-years & $\begin{array}{c}-0.010 \\
(-0.113)\end{array}$ & $\begin{array}{l}0.003 \\
0.033\end{array}$ & $\begin{array}{c}0.022 \\
(0.243)\end{array}$ \\
\hline Handicap & $\begin{array}{c}-0.015 \\
(-0.386)\end{array}$ & $\begin{array}{c}-0.016 \\
(-0.403)\end{array}$ & $\begin{array}{c}-0.018 \\
(-0.460)\end{array}$ \\
\hline Schooling & $\begin{array}{l}-0.382^{* *} \\
(-2.430)\end{array}$ & $\begin{array}{l}-0.380^{* *} \\
(-2.421)\end{array}$ & $\begin{array}{l}-0.382^{* *} \\
(-2.451)\end{array}$ \\
\hline S_Mandatory & $\begin{array}{c}0.033 \\
(0.456)\end{array}$ & $\begin{array}{c}0.037 \\
(0.512)\end{array}$ & $\begin{array}{c}0.065 \\
(0.887)\end{array}$ \\
\hline S_Advanced & $\begin{array}{l}-0.015 \\
(-0.196)\end{array}$ & $\begin{array}{l}-0.011 \\
(-0.139)\end{array}$ & $\begin{array}{c}0.020 \\
(0.262)\end{array}$ \\
\hline V_Apprentice & $\begin{array}{l}-0.166^{* *} \\
(-3.883)\end{array}$ & $\begin{array}{l}-0.166^{* *} \\
(-3.901)\end{array}$ & $\begin{array}{l}-0.168^{* *} \\
(-3.965)\end{array}$ \\
\hline V_Advanced & $\begin{array}{c}-0.067 \\
(-1.078)\end{array}$ & $\begin{array}{c}-0.068 \\
(-1.090)\end{array}$ & $\begin{array}{l}-0.073 \\
-1.182\end{array}$ \\
\hline German_Spoken & $\begin{array}{c}-0.144^{*} \\
(-1.887)\end{array}$ & $\begin{array}{l}-0.159^{* *} \\
(-2.078)\end{array}$ & $\begin{array}{l}-0.160^{* *} \\
(-1.981)\end{array}$ \\
\hline Catholic & $\begin{array}{c}0.284^{* *} \\
(3.853)\end{array}$ & $\begin{array}{l}0.284^{* *} \\
(3.856)\end{array}$ & $\begin{array}{l}0.284^{* *} \\
(3.878)\end{array}$ \\
\hline Protestant & $\begin{array}{c}0.287^{* *} \\
(3.906)\end{array}$ & $\begin{array}{l}0.287^{* *} \\
(3.911)\end{array}$ & $\begin{array}{c}0.287^{* *} \\
(3.934)\end{array}$ \\
\hline Other_Religions & $\begin{array}{c}0.265 \\
(0.560)\end{array}$ & $\begin{array}{c}0.266 \\
(0.562)\end{array}$ & $\begin{array}{c}0.265 \\
(0.564)\end{array}$ \\
\hline Catholic*Immi & $\begin{array}{l}-0.293^{* *} \\
(-2.730)\end{array}$ & $\begin{array}{l}-0.297^{* *} \\
(-2.771)\end{array}$ & $\begin{array}{l}-0.406^{* *} \\
(-2.994)\end{array}$ \\
\hline Protestant*Immi & $\begin{array}{l}-1.862^{* *} \\
(-1.977)\end{array}$ & $\begin{array}{l}-1.847^{* *} \\
(-1.961)\end{array}$ & $\begin{array}{c}-1.825^{*} \\
(-1.947)\end{array}$ \\
\hline Other_Religions*Immi & $\begin{array}{c}0.073 \\
(0.151)\end{array}$ & $\begin{array}{c}0.068 \\
(0.141)\end{array}$ & $\begin{array}{c}-0.010 \\
(-0.020)\end{array}$ \\
\hline Immigrant & $\begin{array}{c}0.584^{* *} \\
(4.467)\end{array}$ & - & - \\
\hline FYG/10 & $\begin{array}{c}0.324 \\
(0.555)\end{array}$ & - & - \\
\hline$(\mathrm{FYG} / 10)^{2}$ & $\begin{array}{c}-0.560 \\
(-0.502)\end{array}$ & - & - \\
\hline$(\mathrm{FYG} / 10)^{3}$ & $\begin{array}{c}0.207 \\
(0.286)\end{array}$ & - & - \\
\hline$(\mathrm{FYG} / 10)^{4}$ & $\begin{array}{c}-0.019 \\
(-0.129)\end{array}$ & - & - \\
\hline FYG_G0 & - & $\begin{array}{c}0.617^{* *} \\
(4.645)\end{array}$ & - \\
\hline FYG_G1 & - & $\begin{array}{c}0.572^{* *} \\
(4.410)\end{array}$ & - \\
\hline
\end{tabular}


Table 4: continued

\begin{tabular}{|c|c|c|c|}
\hline Variable & $\begin{array}{r}\text { Immigrant } \\
\text { Polynomial } \\
(1) \\
\end{array}$ & $\begin{array}{l}\text { Model (IM) } \\
\text { Categorical } \\
(2) \\
\end{array}$ & $\begin{array}{c}\text { Nationality Model (NM) } \\
\text { Polynomial } \\
(3) \\
\end{array}$ \\
\hline FYG_G2 & - & $\begin{array}{c}0.683^{* *} \\
(5.261)\end{array}$ & - \\
\hline FYG_G3 & - & $\begin{array}{l}0.477^{* *} \\
(3.870)\end{array}$ & - \\
\hline FYG_G4 & - & $\begin{array}{l}0.378^{* *} \\
(3.137)\end{array}$ & - \\
\hline FYG_G5 & - & $\begin{array}{l}0.392^{* *} \\
(3.262)\end{array}$ & - \\
\hline FYG_G6 & 一 & $\begin{array}{l}0.297^{* *} \\
(2.027)\end{array}$ & - \\
\hline N_Turkish & - & - & $\begin{array}{c}0.337 \\
(1.501)\end{array}$ \\
\hline N_Italian & - & - & $\begin{array}{c}1.150^{* *} \\
(5.326)\end{array}$ \\
\hline N_Spanish & - & - & $\begin{array}{c}0.995^{* *} \\
(3.204)\end{array}$ \\
\hline N_Greek & 一 & - & $\begin{array}{c}0.262 \\
(0.657)\end{array}$ \\
\hline N_Yugoslav & - & - & $\begin{array}{c}0.791^{* *} \\
(4.310)\end{array}$ \\
\hline$\phi$ & 0.876 & 0.876 & 0.863 \\
\hline Number of observations & 2093 & 2093 & 2093 \\
\hline
\end{tabular}

Note: 1. Approximative t-statistics in parantheses. 2. The polynomial nationality model additionally controls for nationality-specific third order polynomials, which are not presented to save space. 
Figure 1: Completed fertility according to the assimilation hypothesis

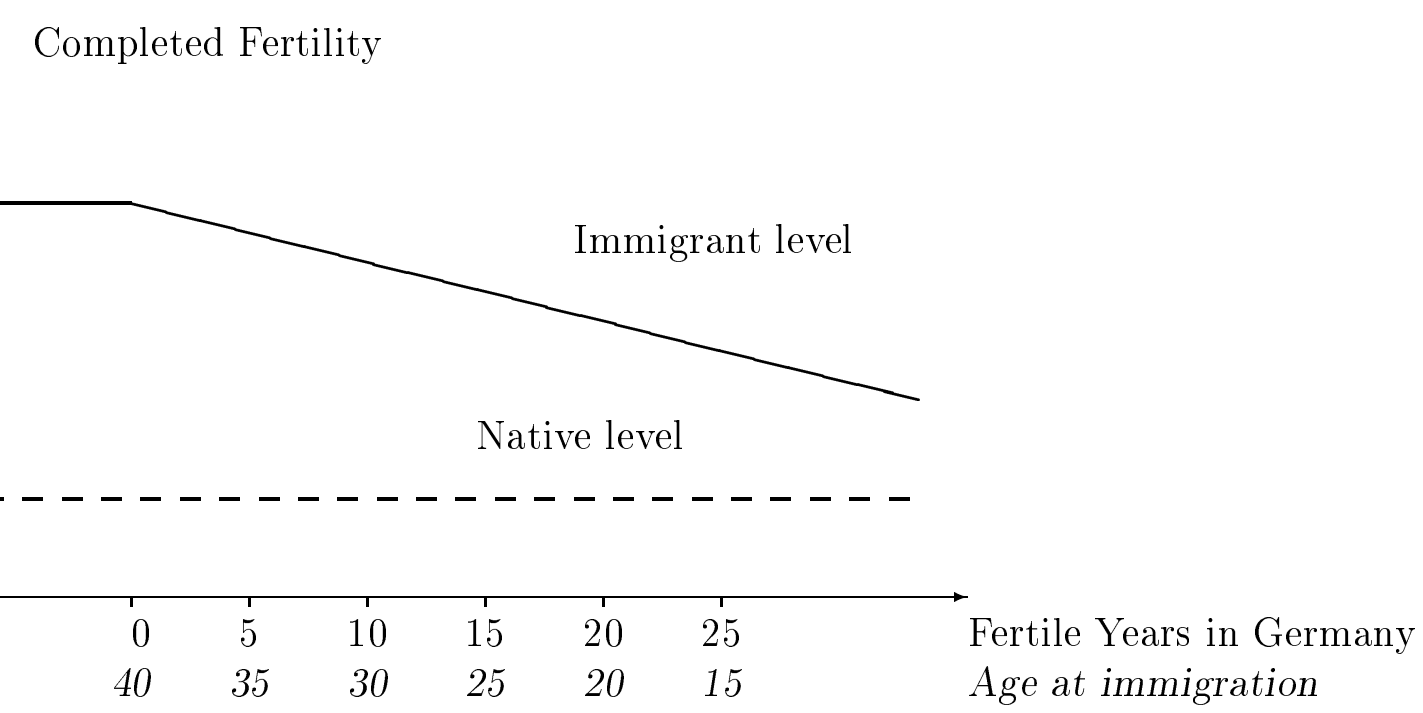

Figure 2: Completed fertility according to different disruption hypotheses

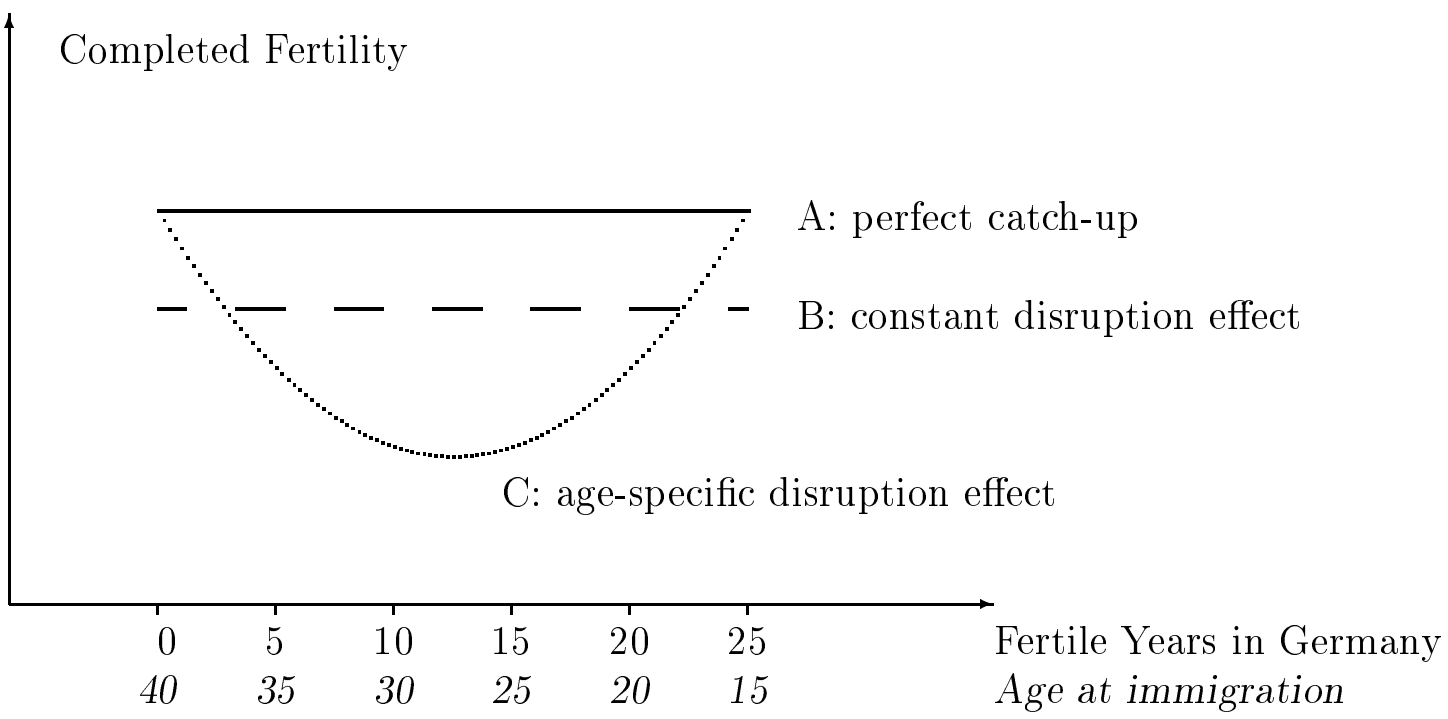


Figure 3: Average completed fertility by fertile years in Germany

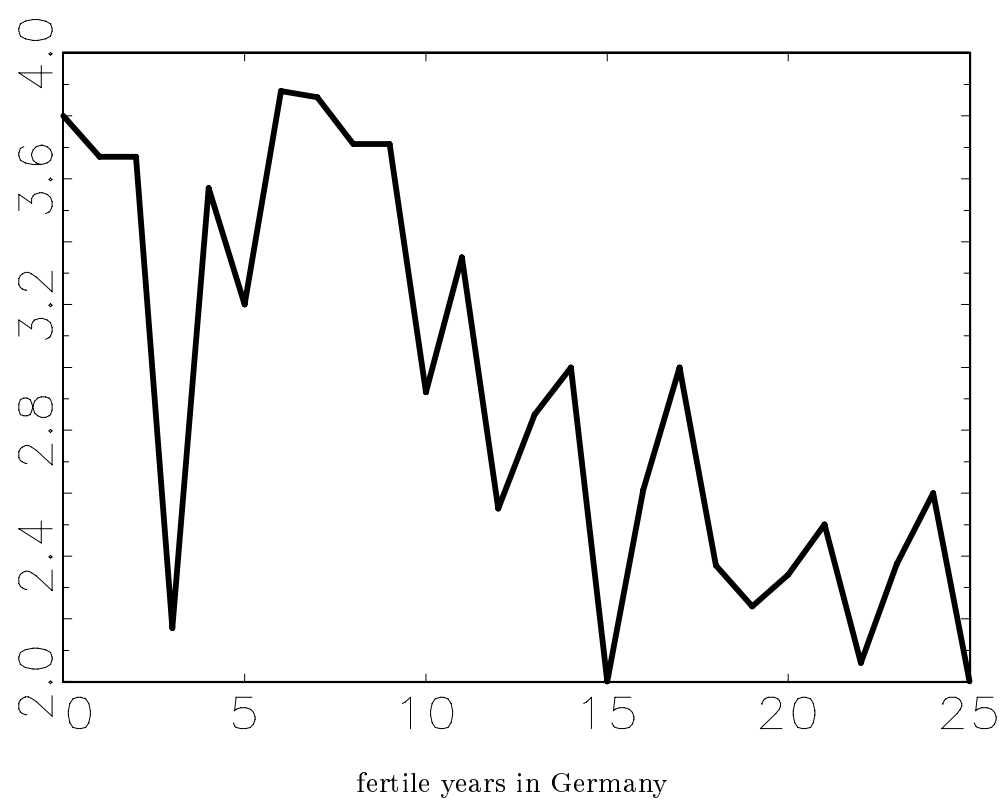

Source: Own calculations based on German Socioeconomic Panel (GSOEP) 
Figure 4: Impact of being an immigrant as a function of FYG

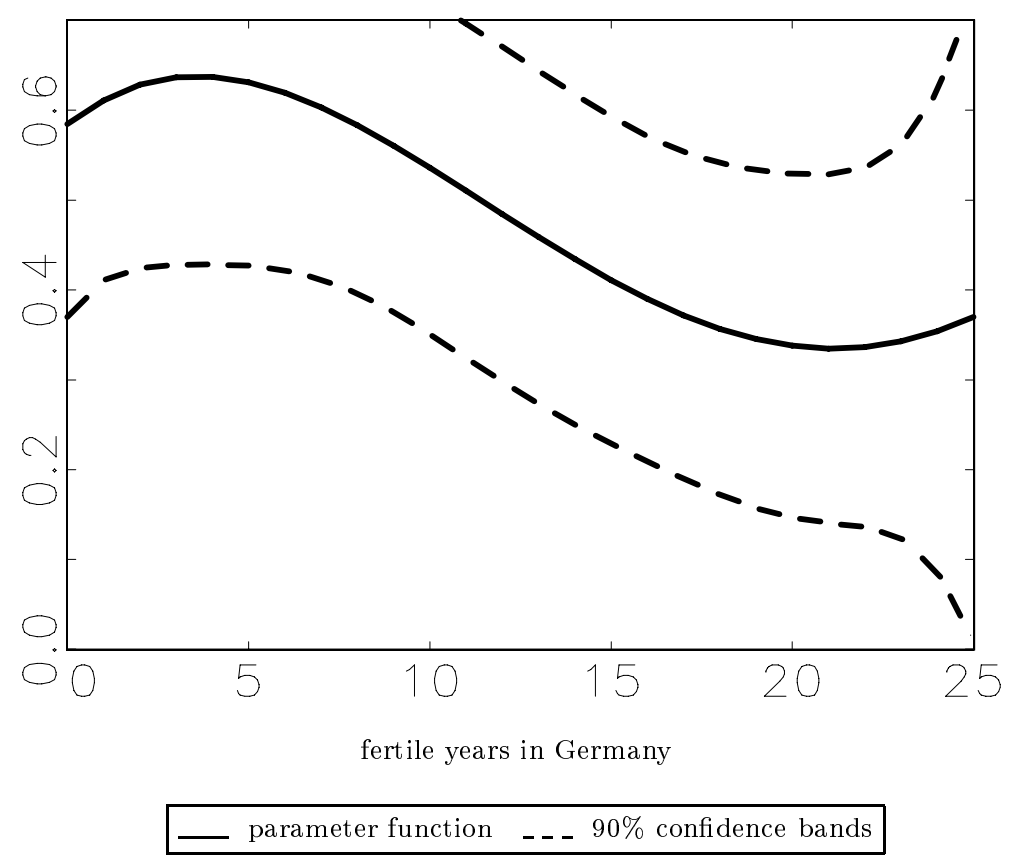

Figure 5: Impact of being an immigrant as a function of FYG with and without the observations having more than 20 FYG

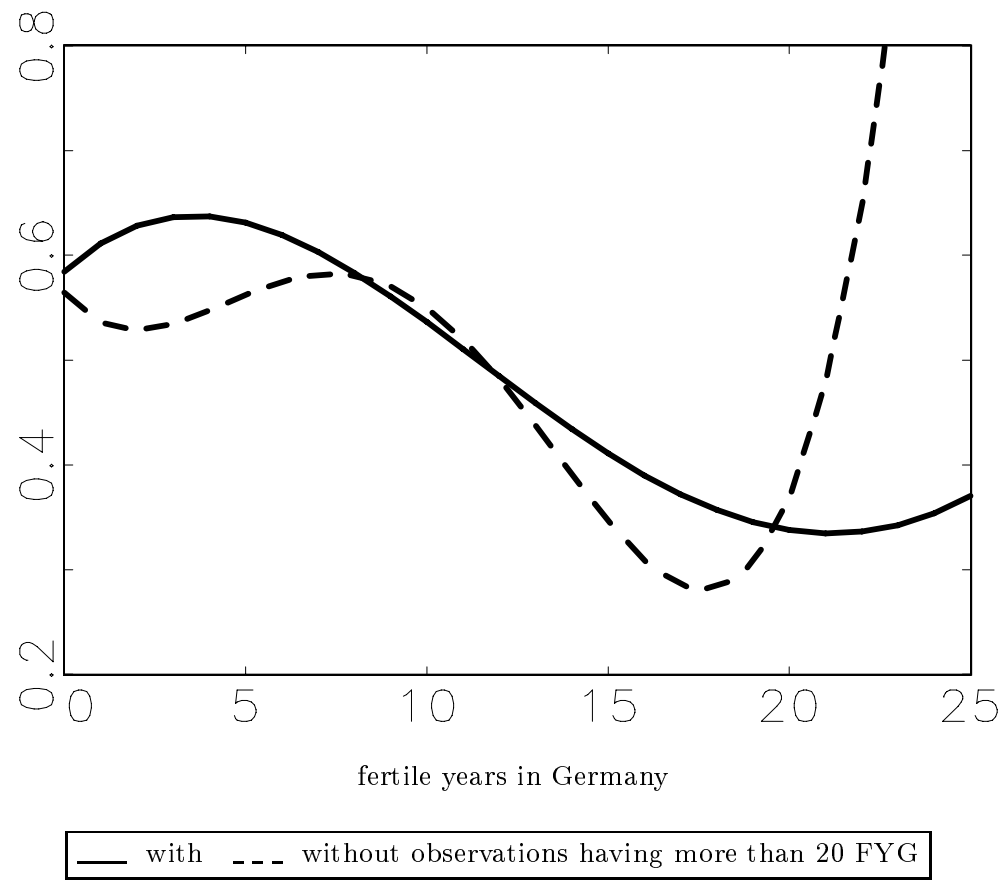


Figure 6: Impact of being an immigrant according to polynomial and categorical specification as a function of FYG

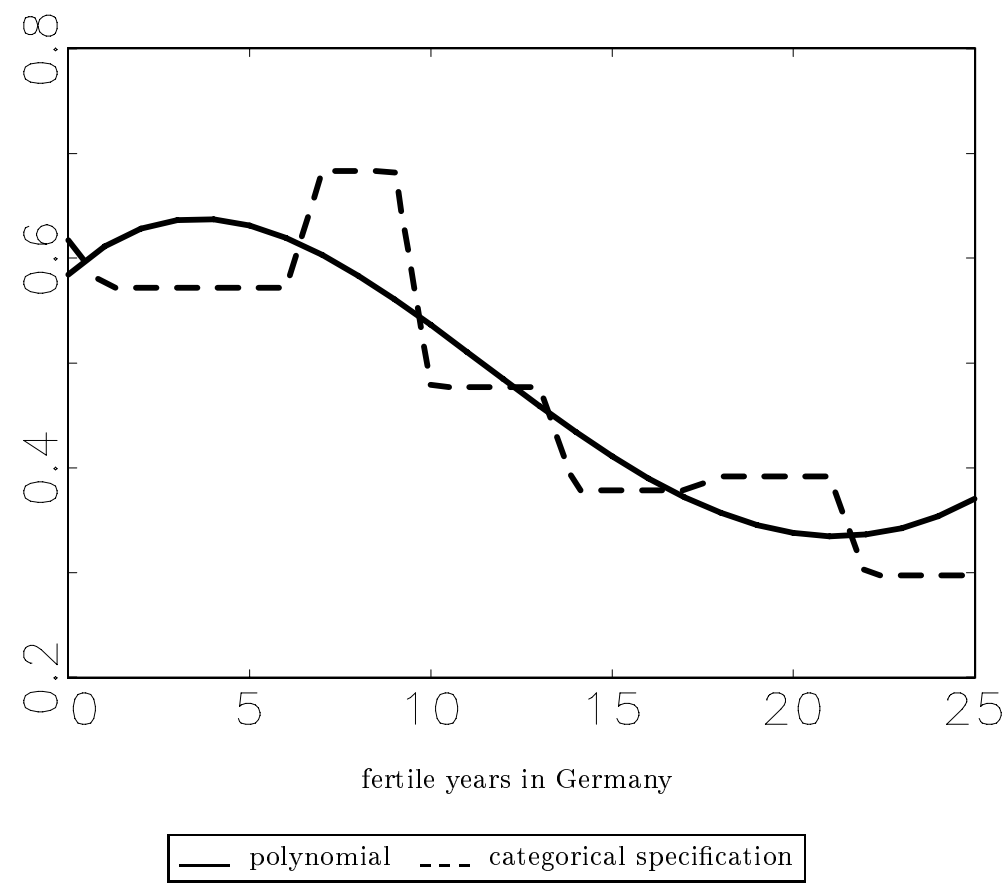

Figure 7: Impact of being Turkish as a function of FYG according to polynomial specification

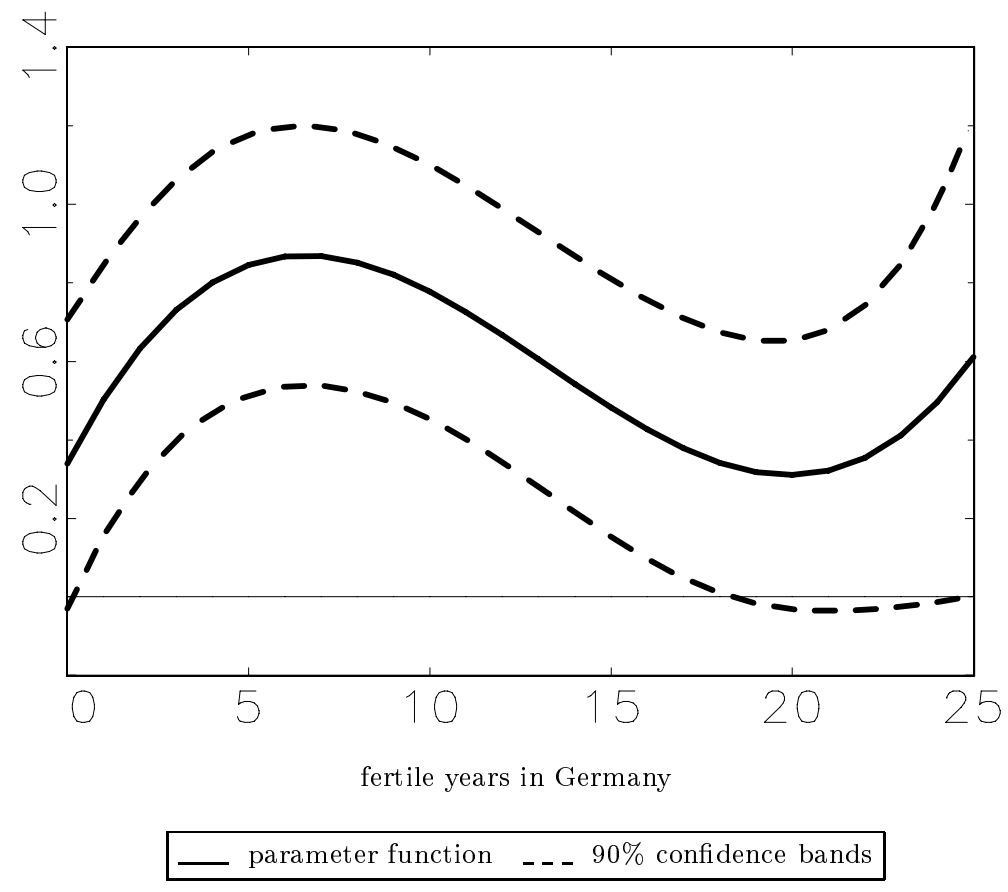


Figure 8: Impact of being Italian as a function of FYG according to polynomial specification

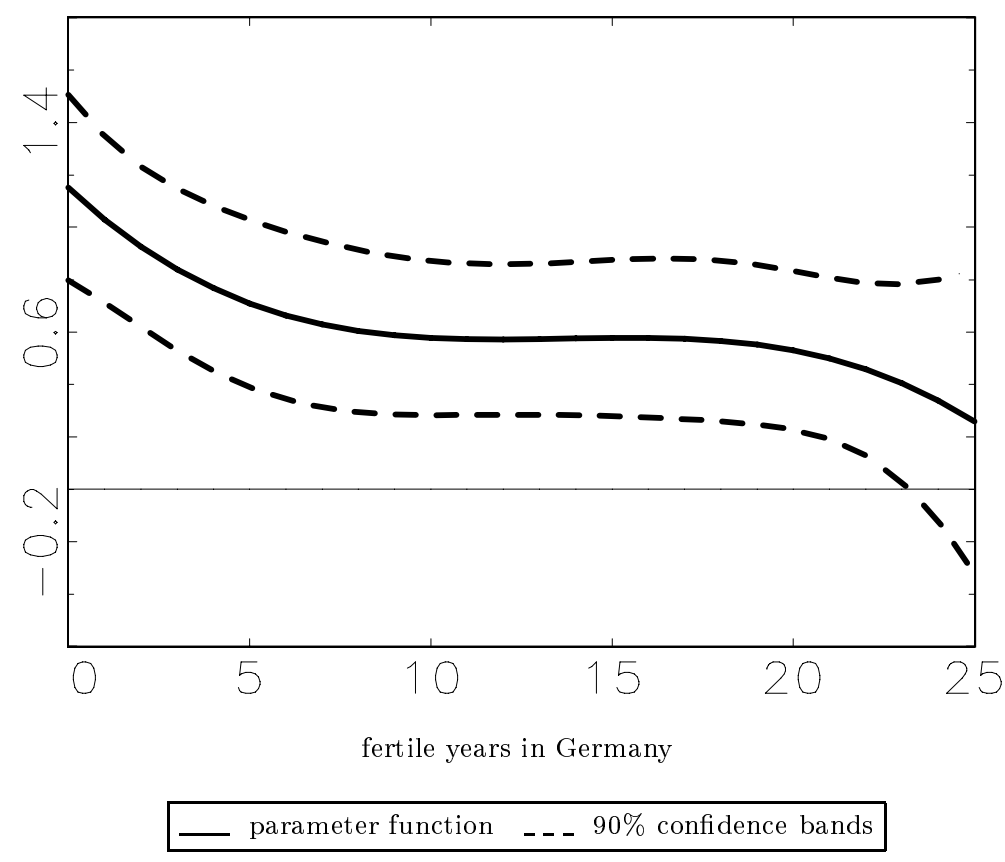

Figure 9: Impact of being Spanish as a function of FYG according to polynomial specification

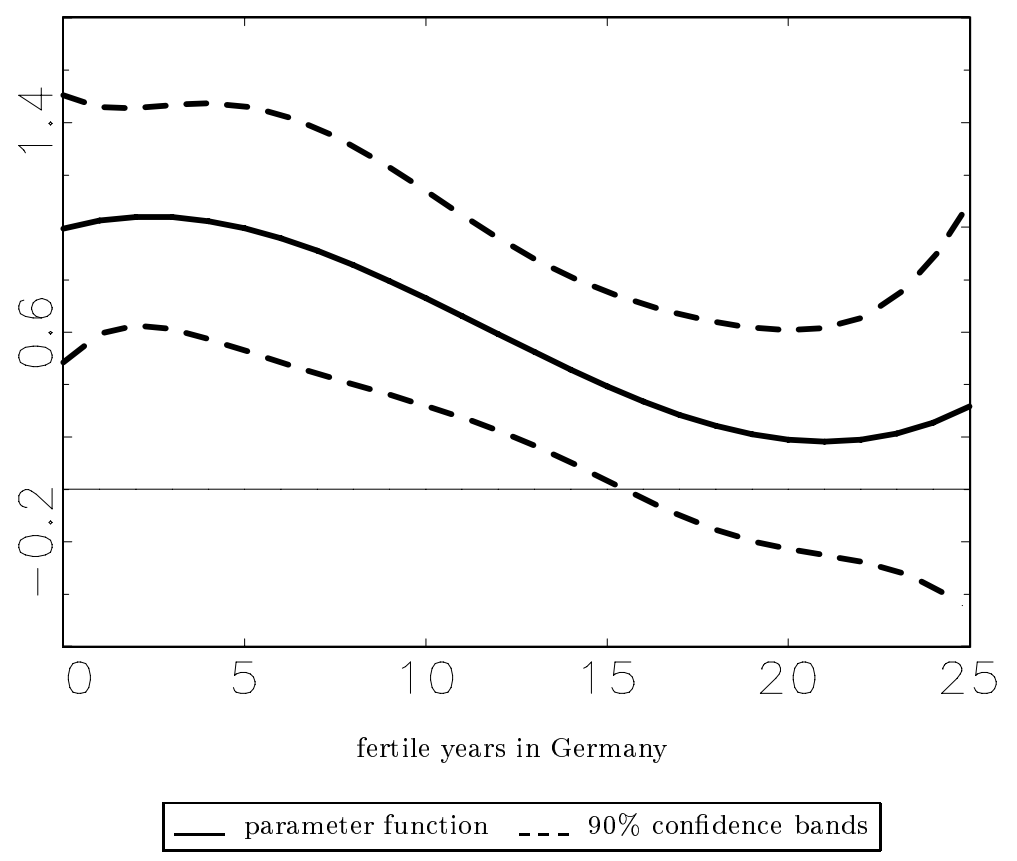


Figure 10: Impact of being Greek as a function of FYG according to polynomial specification

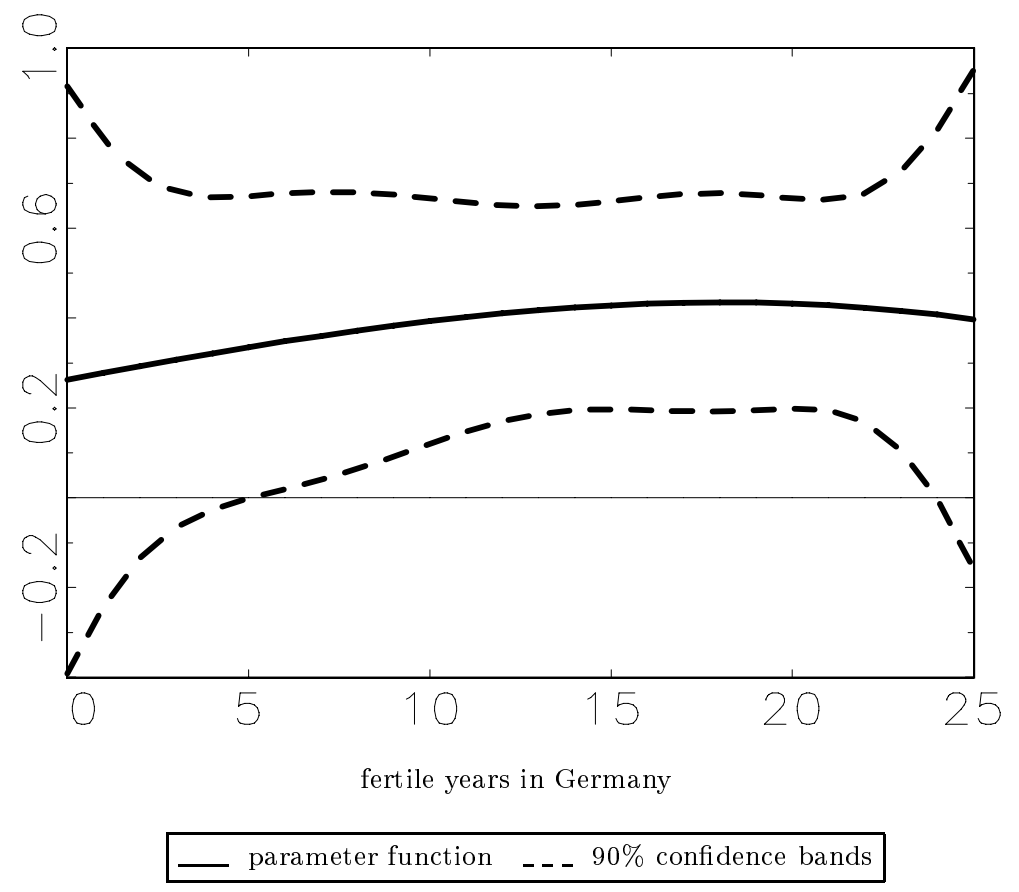

Figure 11: Impact of being Yugoslavian as a function of FYG according to polynomial specification

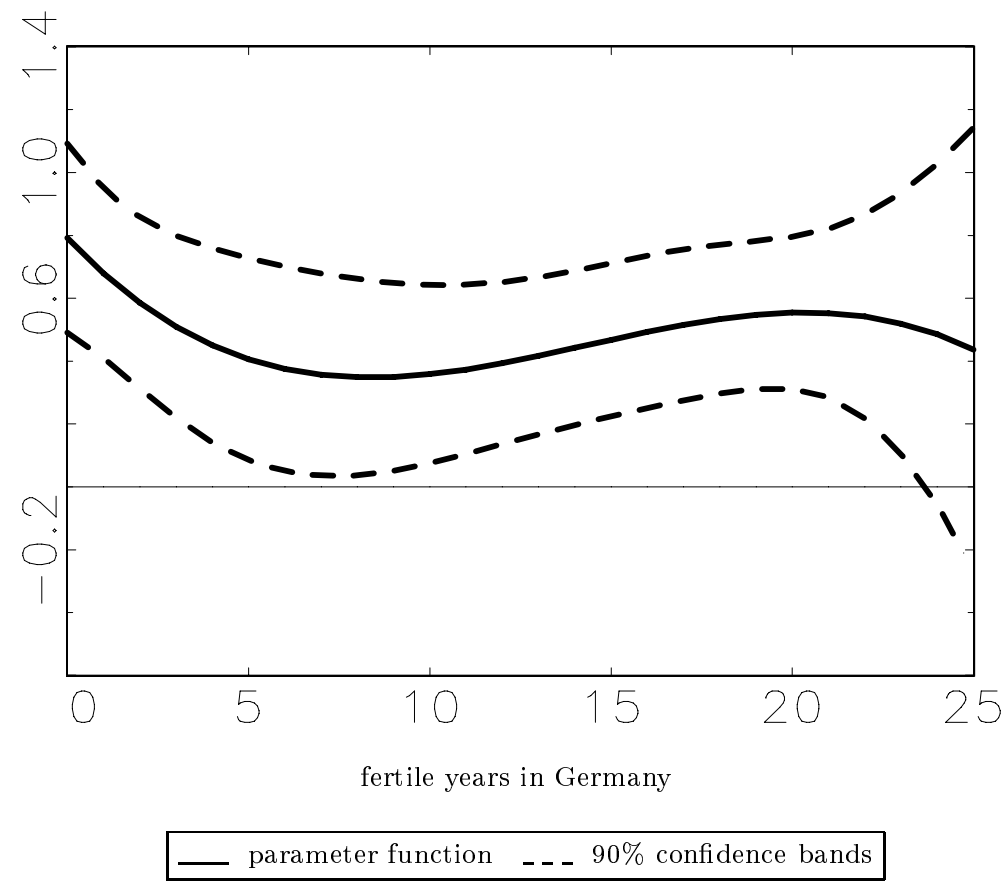

